This is the authors' final draft. Please consult the published version of the article for proper pagination and for citation:

Devlin, Frances and E. Bruce Hayes. "A Faculty/Librarian Collaboration to Restructure a Graduate Research Methods Class for French Literature Students.” The French Review. 89.2 (December 2015): 146-163.

Frances Devlin and E. Bruce Hayes

fadevlin@ku.edu, bhayes@ku.edu

University of Kansas, Lawrence, KS 66045

\title{
A Faculty/Librarian Collaboration to Restructure a Graduate Research Methods Class for French Literature Students
}

\section{by Frances Devlin and E. Bruce Hayes}

IN THE 2012 SPRING SEMESTER, Bruce Hayes, Director of Graduate Studies, French Department, and Frances Devlin, Librarian for French Literature, University of Kansas, collaborated to restructure and teach Introduction to Graduate Studies in French, a 3credit research methods graduate class. One important aspect of this faculty/librarian collaboration was in the development of a relatively new model of instruction in which a librarian was "embedded" in the class and attended all sessions. Instead of offering a typical “one-shot” (one class period) library session, relevant information sources and research strategies were integrated throughout the class. The purpose was to build the graduate students' research skills with a series of assignments, from developing a search strategy, to finding relevant sources to support a research statement, to preparing an annotated bibliography, to submitting a paper proposal, and culminating in delivering a conference paper. In addition, other librarians and subject experts were invited into the class throughout the semester to present on scholarly topics such as digital humanities research, copyright management, scholarly communications, open access, research 
impact factors, and working with special and rare collections. While the course included the elements of a traditional bibliography and research methods class, the other major component was a focus on students developing practical, professionally useful skills, an awareness of higher education issues, and an introduction to alternative academic and non-academic careers. These practical skills included: creating a web-based professional portfolio with an academic CV and a professional resume; creating blogs and commenting on higher-education issues and literary theory; writing grant proposals; and participating in a panel discussion on alternative academic careers for humanists with advanced degrees. The class was offered a second time in the 2013 fall semester and was expanded to include graduate students from the Slavic and German departments to increase the interdisciplinary nature of the course, since many of the topics covered were of common interest to all. By collaborating with these other two language departments, the Introduction to Graduate Studies class can now be offered annually as part of the curriculum for new graduate students.

\section{Class Description}

\section{Syllabus/Assignments}

Alain-Philippe Durand's 2013 article in the French Review generated lively discussion on our campus and elsewhere about strategies for recruiting French majors. One of Durand's main points is that we need to recognize that most of our students who major in French and Francophone studies will not pursue careers directly related to the field. He did an excellent job explaining how we can view this positively and how we can change our message to students to explain why studying French will benefit them. 
In redesigning this course, we began by considering an issue similar to the one Durand raises, but at the graduate level: first, while many of the graduate students in our program will go on to teach French, either at the secondary or post-secondary level, many others will not. Also, while some of our students at the MA level will go on to pursue PhDs in French, others will not. Acknowledging these realities, which have generated enormous discussion and debate nationally, ${ }^{1}$ led us to the following questions that guided our development of this new, hybridized introductory course to graduate studies: What can we do to better prepare students who do not go on to a career teaching and conducting research in French studies in a way that will also benefit those who do? Next, what can we do to better integrate technology into this class in ways that are pedagogically and professionally useful? How do we introduce our graduate students to digital humanities, website design, research management tools, and others? How do we do all of this while still preserving the core mission of the class, which is to train students how to conduct graduate-level research and produce the kind of research paper that will benefit them in their training as future scholars and teachers?

Given our mutual limitations as a professor and a librarian, attempting to address such a large number of skills and training required a large degree of collaboration. By the time the course design was complete, we had liaised with more than a dozen people from various offices and departments on campus. Professors will often schedule training sessions for classes with these different offices on campus (e.g., the Libraries, the Writing Center, Career Services, etc.). The efficacy of these one-off sessions is limited, since they involve very little student engagement. As we prioritized the training we wanted to include for this class, we worked to ensure that whatever we did, there was a well-defined 
assignment connected with it, as well as a follow-up session to verify student engagement. For example, when we worked with our digital humanities specialist, the goal was to design a detailed assignment for the students that would require them to use at least one digital humanities tool to investigate a French literary text. In addition to an introductory session illustrating how to use various digital humanities tools and out-ofclass times provided for students to come for help, the culminating event was a "show and tell” class where the students in the course presented the results of their digital humanities projects. $^{2}$

For the website-design element of this class, we collaborated with our colleagues at the Academic Resource Center to provide training. By the second week of class, students had set up their own websites and had two separate blogs, one on literary theory (we used an Open Yale course, Paul H. Fry’s “Introduction to Theory of Literature” <oyc.yale.edu/english/engl-300>, which the students blogged about and we discussed in class), and another on topics related to higher education, foreign language instruction, graduate studies, and the job market. This latter category contributed to increasing professional awareness by our students, most of whom were unaware of the issues surrounding our profession, including the dire academic job market. Students were also able to use their websites to develop online teaching portfolios.

Another important aspect of this course was training students how to use materials in a rare-book research library. To do this, we worked with our colleagues at our research library to design an assignment that would allow them to work with physical materials in the library and report the results of their research. Our library has a fairly strong collection of French Revolution-era pamphlets, numbering in the thousands, most of 
which are not accessible in the online catalog. This required them to use a print bibliography to find a pamphlet that interested them, and we also asked them to use the National Union Catalogue and WorldCat to identify other libraries with copies of the same pamphlet. The best part of this assignment was the "show and tell" class where we gathered in a reading room with all of the chosen pamphlets on display and the students were able to talk about their pamphlets and contextualize them historically. This was a much better experience than previous ones that had simply involved a tour of the library and a cursory examination of some of the holdings.

In addition to library research-methods training, which involved the traditional introduction to online and print resources for French and Francophone studies, we included the requirement that students use a reference management and "cite and write" tool such as Zotero. Instead of simply having a session in which the program was introduced, we broke it down into two parts and required students to build their own digital library and then use the citation management function when writing their paper for the course. Students found it very useful to be required to do this, because once they had been through the experience of setting up a digital library and seen the benefit of the "cite and write" tool for their paper, this became a resource they used frequently throughout their graduate studies.

As mentioned previously, the central requirement of this class is a research paper, which we broke down into several steps. Instead of following the traditional model of requiring a research paper at the end of the class, we started with an annotated bibliography, followed by an abstract (we did two versions, with only the second version being graded), then a paper outline, followed by a first submission of the paper a few 
weeks before the end of the semester. This allowed the instructor to provide feedback, as well as feedback from selected peers, before students submitted their final paper at the end of the semester. Having taught several graduate courses before this one, the faculty member found that the general quality of the final work was much improved compared to previous courses.

When we offered the course again in 2013, we made another change that provided an additional element of professional development for our students. On the last Saturday of the term, we held a mock conference where students presented their papers to their peers and other faculty members. ${ }^{3}$ The conference was successful and those who attended were impressed with the quality of the presentations. More importantly, it provided our students with the confidence and experience to submit abstracts to present at other conferences. Multiple students reported within the year that they had presented at a national conference and that they would never have done this as early in their graduate studies, if it were not for the experience of this course.

\section{Assessment/Feedback}

Surveys were administered to the students at the end of each semester to ask for feedback about the class structure, assignments, required readings, and the presence of a librarian, along with other specialists in the class. We also asked if there were other topics or research skills that they would have liked to have learned, but were not included in the course. The feedback was positive both times the class was taught and students enjoyed the experience of having a librarian embedded in the classroom. Based on the input provided by students and others involved in teaching the class, the structure and 
content has been modified and improved each time it has been offered. After the first iteration of the class, we realized that we were attempting to cover too many topics without sufficient depth. Subsequently, we chose those training sessions identified as most valuable and allocated more time to them. For example, the digital humanities training was expanded to devote more class time, including the assignment previously described. Also, students requested more literary theory. The second time the class was offered, an expanded number of literary theories were addressed and students were required to produce blogs about them.

Overall, the highest ratings from the survey (Appendix 2) were given for the "AltAc” Panel, the Career Services CV and resume preparation, and the digital humanities sessions. Both times the class was offered, the majority of the students responded that this experience had increased their confidence in conducting library research from searching for relevant materials, to preparing an annotated bibliography, writing an abstract, and delivering a conference paper.

\section{Significance}

“Embedded” Librarian

Embedding librarians into a classroom has been a growing practice in academic libraries over the past decade to integrate information literacy and research skills into the curriculum. One of the benefits of moving to this model of instruction has been the resulting stronger relationships established between the students, the faculty member, and the librarian. It also illustrates the changing role of librarians in higher education and the value in collaborating more closely with faculty members in teaching. The term 
"embedded" is inspired by embedded journalists who worked in close proximity to the military during wartime media coverage. While there are many interpretations or definitions, Barbara Dewey is one of the first authors to use the phrase "embedded librarian." She provides examples and emphasizes the "imperative for academic librarians to become embedded in the priorities of teaching, learning, and research” (6). Since her article, several publications have described various implementations of “embedded librarians” working with faculty. These range from embedding an online component (a library guide, tutorial, etc.) into a course, to having a librarian embedded into a course management system, such as Blackboard, to a librarian having a presence in a department or school, to being fully integrated into a course (Schulte).

One of the goals in having a librarian embedded in our course was to provide more time over several classes for in-depth coverage of research tools and methods. We also wanted to increase student awareness that librarians are valuable partners to assist them in the research process. Students are often hesitant to approach librarians to ask for assistance. By being present in the class throughout the semester, the librarian became a part of the group, someone who was approachable and easily accessible for consultation. The librarian was also able to work closely with the students to gain better knowledge of their research needs throughout the class. In a one-shot library session, there is typically not adequate time for in-depth coverage of specific library resources or advanced research skills (Bean and Thomas). In our case, the presence of a librarian in all the classes allowed for regular opportunities for the students to interact with her about their assignments, thus building connections that will last throughout their graduate studies. 


\section{Preparing Future French Scholars, Alt-Academic Careers}

As previously mentioned, one of the prime motivators for modifying our course was acknowledging the generations-old problem, made worse by the economic meltdown of 2007-08, of too many PhDs and not enough academic positions. While some of our graduates go on to be French teachers and professors, others do not. One of the goals of this class has been to help students become aware of this sooner and provide them with better tools for tackling this challenge. Nationally, this is a hot topic and one that has generated a fair amount of controversy. Most recently, Georgetown's launching of an "alt-ac" PhD in English brought out strong reactions on both sides of the debate (Patel). Based on student feedback, one of the most successful aspects of this class has been "alternative academic" or "alt-ac" training. When students were polled about favorite activities, the "alt-ac" panel discussion we organized ranked the highest. We invited four upper-level administrators on campus who have humanities PhDs to participate. Speakers were asked to consider the following questions:

- What do you know now that you wish you had known when you were starting out in graduate school?

- What can students be doing now to prepare better for an "alt-ac" career?

- What skills/knowledge did you acquire during your graduate studies that have benefited you professionally?

- What are the pros and cons about your career choice?

The discussion was lively and everyone was engaged. Several students commented that it was helpful to meet people who had successfully made the transition. This experience 
also put students in contact with people who could serve as mentors and provide guidance to those interested in pursuing different careers after graduate school.

Another popular session, which ranked second on student surveys, was the handson training provided by our colleague in career services. She guided students through the process of finding a job description that interested them and then tailoring their application materials to the position description. She helped them understand the important differences and nuances between CVs and resumes, and how to write effective cover letters for both French teaching positions and administrative jobs (having served on hiring committees for administrative positions, Hayes has been dismayed by the number of humanities $\mathrm{PhD}$ applicants who clearly do not understand how to adapt their application materials for an administrative position). We have expanded this portion of the class to include setting up online profiles on Academia.edu or LinkedIn, as well as managing one's online research profile using tools such as ORCid.

While this class included elements intended to help those who might go on to a career outside the professoriat, these elements can be beneficial to those wishing to become French teachers as well. The reality is that those of us who teach French spend an inordinate amount of time doing administrative tasks and that we receive little or no training or preparation for this in graduate school. Providing some of this training for our students can be beneficial not just for those who want to pursue careers outside teaching, but for those who pursue a career in teaching and research as well.

\section{Looking to the Future}


A key element to the success of this teaching experience has been the strong working relationship and collaborative process between the faculty member and the librarian throughout this class. Changes are made based on our experiences in teaching the class, in addition to using the feedback and data collected from students through the surveys. Although our campus has limited resources, we were able to secure modest funding to support the class redesign. The course was awarded a grant in 2014-15 from the Institute for Digital Research in the Humanities <idrh.ku.edu/course-developmentgrants $>$ to help us further integrate digital humanities into the course.

The next time the class is offered, we plan to gather additional quantitative data with pre- and post-assessment surveys to determine students' knowledge of research tools at the beginning and at the end of the semester. The quality of students' research output (annotated bibliography, abstract, and conference paper) may also be used as a measure to evaluate the effectiveness of the course content with respect to improving information literacy outcomes for this and other graduate-level classes offered in the French Department.

As we continue to track and expand data we are gathering related to this course, another important element will be job placement and surveying French graduates to ascertain in which ways this course helped to prepare them for their careers. We already have some anecdotal evidence that graduates have found skills they acquired in the class helpful in their academic and professional pursuits. We want to know about our graduates' employment and ask them to identify aspects of this class that they find contributed to their professional success. It will be interesting to compare results between those who have gone on to teach French and those who have pursued other careers. What 
commonalities or differences will we discover between the two groups? This information will be important in making decisions about the future shape of this course and in determining where we will place our greatest emphasis and resources.

UNIVERSITY OF KANSAS

\section{Appendix 1}

Selected content from syllabus, Introduction to Graduate Studies (French 720)

This course is an introduction to the skills required of students doing graduate degrees in French and Francophone Studies. Areas covered include:

1) Introduction to literary theory and criticism

2) Bibliography and research methods, including online database management

3) Preparation and presentation of a research-based conference paper

4) Technology training, including web design, online portfolio, and digital humanities

5) Professional ethics and awareness of the academic market and alternative careers

We will also be working on practical, professionally useful goals, such as how to make better use of technology, how to create a CV and/or a resume, how to write an abstract, and how to present a conference paper. Course requirements will include a variety of smaller assignments and two larger projects, a web-based professional portfolio and a conference paper.

Required books for all students: 
Booth, Wayne C., Gregory G. Colomb, and Joseph M. Williams. The Craft of Research. $3^{\text {rd }}$ ed. Chicago: UP of Chicago, 2008.

Fry, Paul H. Theory of Literature. New Haven: Yale UP, 2012.

Semenza, Gregory M. Colón. Graduate Study for the Twenty-First Century: How to Build an Academic Career in the Humanities. $2^{\text {nd }}$ ed. New York: Palgrave Macmillan, 2010.

For French graduate students, you must select one of the following works (your research paper will be based on one of these books):

Navarre, Marguerite de. Heptaméron.

Flaubert, Gustave. Madame Bovary.

Work Required:

Attendance and active class participation

Attendance at three campus events, including at least one digital humanities event (submit via email a one-paragraph description within one week of event)

Website (this will include blogs on higher education and literary theory, academic CV or professional resume, personal profile, digital humanities project, and overall design)

Spencer Research Library project

Annotated bibliography (at least a dozen secondary sources)

Conference paper abstract (275-300 words) 


\section{Conference paper outline}

Oral presentation of paper

Conference paper, final version (9-10 pages; 2700-3000 words plus substantial bibliography)

\section{Sample Activities from the Syllabus}

Thu Aug $28 \quad$ Website design training

Tue Sep 2 Introduction to Digital Humanities

Thu Sep $4 \quad$ Library Research Methods [this was the first of three sessions held by the French librarian]

Tue Sep $9 \quad$ Zotero training

Tue Oct $21 \quad$ Spencer Research Library: Working in research libraries

Tue Oct 28 Digital Humanities Project: "Show and Tell”

Tue Nov 4 KU Career Services: CV and resume workshop

Tue Nov 11 Panel Discussion-Careers for humanities graduate students [We included four different administrators with advanced degrees in the humanities, including French] 


\begin{tabular}{|l|l|l|l}
\hline Thu Nov 13 & Spencer Research Library: "Show and Tell”-student \\
& presentations \\
\hline Tue Nov 18 & Online research visibility and open access \\
\hline Thu Nov 20 & Grant writing \\
\hline Tue Dec 2 & Follow-up session with Career Services-CVs, resumes, \\
& and online profiles \\
Sat Dec 6 & Mock Conference \\
\end{tabular}




\section{Appendix 2 \\ Introduction to Graduate Studies Student Survey - Fall 2013}

\section{Was the sequence of topics in this course helpful?}

\begin{tabular}{|c|l|c|c|c|}
\hline$\#$ & Answer & Response & $\%$ \\
\hline 1 & Yes & 14 & $100 \%$ \\
2 & No & 0 & $0 \%$ \\
\hline & Total & 14 & $100 \%$ \\
\hline
\end{tabular}

\begin{tabular}{lr} 
Statistic & Value \\
\hline Min Value & 1 \\
Max Value & 1 \\
Mean & 1.00 \\
Variance & 0.00 \\
Standard Deviation & 0.00 \\
Total Responses & 14
\end{tabular}

\section{Please rate the texts used for this class:}

\begin{tabular}{|c|c|c|c|c|c|c|c|}
\hline \# & Question & $\begin{array}{l}\text { Not at } \\
\text { all } \\
\text { helpful }\end{array}$ & $\begin{array}{l}\text { Somewhat } \\
\text { helpful }\end{array}$ & Helpful & $\begin{array}{l}\text { Very } \\
\text { helpful }\end{array}$ & $\begin{array}{c}\text { Total } \\
\text { Responses }\end{array}$ & Mean \\
\hline 1 & $\begin{array}{l}\text { The Craft of } \\
\text { Research.(Booth, } \\
\text { Colomb, } \\
\text { Williams) }\end{array}$ & 0 & 6 & 5 & 3 & 14 & 2.79 \\
\hline 2 & $\begin{array}{l}\text { Graduate Study } \\
\text { for the Twenty- } \\
\text { First Century: } \\
\text { How to Build an } \\
\text { Academic Career } \\
\text { in the } \\
\text { Humanities. } \\
\text { (Semenza) }\end{array}$ & 0 & 1 & 4 & 9 & 14 & 3.57 \\
\hline 3 & $\begin{array}{l}\text { Theory of } \\
\text { Literature. (Fry) }\end{array}$ & 2 & 2 & 4 & 6 & 14 & 3.00 \\
\hline
\end{tabular}




\begin{tabular}{l|c|c|c|}
\hline Statistic & $\begin{array}{c}\text { Graduate Study for } \\
\text { The Craft of } \\
\text { Research.(Booth, } \\
\text { Colomb, Williams) } \\
\text { Century: How to } \\
\text { Build an Academic } \\
\text { Career in the } \\
\text { Humanities. } \\
\text { (Semenza) }\end{array}$ & $\begin{array}{c}\text { Theory of } \\
\text { Literature. (Fry) }\end{array}$ \\
\hline Min Value & 2 & 2 & 1 \\
Max Value & 4 & 4 & 4 \\
Mean & 2.79 & 3.57 & 3.00 \\
Variance & 0.64 & 0.42 & 1.23 \\
Standard Deviation & 0.80 & 0.65 & 1.11 \\
Total Responses & 14 & 14 & 14 \\
\hline
\end{tabular}

\section{Did you find it helpful having a librarian in your} class?

\begin{tabular}{|c|l|c|c|c|}
\hline$\#$ & Answer & Response & $\%$ \\
\hline 1 & Yes & 11 & $79 \%$ \\
2 & No & 3 & $21 \%$ \\
\hline & Total & 14 & $100 \%$ \\
\hline
\end{tabular}

\section{Statistic}

Min Value

Max Value

Mean

Variance

Standard Deviation

Total Responses
Value

1.21

0.18

0.43

14 


\section{Please rate the following class activities:}

\begin{tabular}{|c|c|c|c|c|c|c|c|}
\hline \# & Question & $\begin{array}{l}\text { Not at } \\
\text { all } \\
\text { helpful }\end{array}$ & $\begin{array}{l}\text { Somewhat } \\
\text { helpful }\end{array}$ & Helpful & $\begin{array}{c}\text { Very } \\
\text { helpful }\end{array}$ & $\begin{array}{c}\text { Total } \\
\text { Responses }\end{array}$ & Mean \\
\hline 1 & $\begin{array}{l}\text { EndNote } \\
\text { training }\end{array}$ & 1 & 3 & 4 & 4 & 12 & 2.92 \\
\hline 2 & $\begin{array}{l}\text { Weebly } \\
\text { training }\end{array}$ & 0 & 3 & 7 & 3 & 13 & 3.00 \\
\hline 3 & $\begin{array}{l}\text { Spencer } \\
\text { Research } \\
\text { Library }\end{array}$ & 2 & 4 & 3 & 5 & 14 & 2.79 \\
\hline 4 & $\begin{array}{l}\text { Digital } \\
\text { Humanities }\end{array}$ & 0 & 3 & 6 & 5 & 14 & 3.14 \\
\hline 5 & $\begin{array}{l}\text { KU Career } \\
\text { Services } \\
\text { CV I } \\
\text { resume } \\
\text { workshop }\end{array}$ & 1 & 1 & 6 & 5 & 13 & 3.15 \\
\hline 6 & $\begin{array}{l}\text { Research } \\
\text { visibility } \\
\text { and open } \\
\text { access }\end{array}$ & 0 & 4 & 4 & 4 & 12 & 3.00 \\
\hline 7 & $\begin{array}{l}\text { Humanities } \\
\text { alt-ac } \\
\text { panel }\end{array}$ & 0 & 3 & 3 & 8 & 14 & 3.36 \\
\hline 8 & $\begin{array}{l}\text { Time } \\
\text { tracking } \\
\text { activity }\end{array}$ & 1 & 2 & 4 & 6 & 13 & 3.15 \\
\hline
\end{tabular}




\begin{tabular}{|c|c|c|c|c|c|c|c|c|}
\hline Statistic & $\begin{array}{l}\text { EndN } \\
\text { ote } \\
\text { trainin } \\
\quad g\end{array}$ & $\begin{array}{l}\text { Wee } \\
\text { bly } \\
\text { traini } \\
\text { ng }\end{array}$ & $\begin{array}{c}\text { Spenc } \\
\text { er } \\
\text { Resear } \\
\text { ch } \\
\text { Library }\end{array}$ & $\begin{array}{c}\text { Digital } \\
\text { Humanit } \\
\text { ies }\end{array}$ & $\begin{array}{c}\text { KU } \\
\text { Career } \\
\text { Servic } \\
\text { es CV / } \\
\text { resum } \\
\text { e } \\
\text { worksh } \\
\text { op }\end{array}$ & $\begin{array}{c}\text { Resear } \\
\text { ch } \\
\text { visibilit } \\
\text { y and } \\
\text { open } \\
\text { access }\end{array}$ & $\begin{array}{l}\text { Humanit } \\
\text { ies alt- } \\
\text { ac panel }\end{array}$ & $\begin{array}{c}\text { Time } \\
\text { tracki } \\
\text { ng } \\
\text { activit } \\
y\end{array}$ \\
\hline $\begin{array}{l}\text { Min } \\
\text { Value }\end{array}$ & 1 & 2 & 1 & 2 & 1 & 2 & 2 & 1 \\
\hline $\begin{array}{l}\text { Max } \\
\text { Value }\end{array}$ & 4 & 4 & 4 & 4 & 4 & 4 & 4 & 4 \\
\hline Mean & 2.92 & 3.00 & 2.79 & 3.14 & 3.15 & 3.00 & 3.36 & 3.15 \\
\hline $\begin{array}{l}\text { Varianc } \\
\text { e }\end{array}$ & 0.99 & 0.50 & 1.26 & 0.59 & 0.81 & 0.73 & 0.71 & 0.97 \\
\hline $\begin{array}{l}\text { Standar } \\
d \\
\text { Deviatio } \\
n\end{array}$ & 1.00 & 0.71 & 1.12 & 0.77 & 0.90 & 0.85 & 0.84 & 0.99 \\
\hline $\begin{array}{l}\text { Total } \\
\text { Respon } \\
\text { ses }\end{array}$ & 12 & 13 & 14 & 14 & 13 & 12 & 14 & 13 \\
\hline
\end{tabular}




\section{Please rate the following library research topics or resources covered:}

\begin{tabular}{|c|c|c|c|c|c|c|c|}
\hline$\#$ & Question & $\begin{array}{l}\text { Not at } \\
\text { all } \\
\text { helpfu } \\
\text { I }\end{array}$ & $\begin{array}{c}\text { Somewha } \\
\text { t helpful }\end{array}$ & $\begin{array}{l}\text { Helpfu } \\
\text { I }\end{array}$ & $\begin{array}{l}\text { Very } \\
\text { helpfu } \\
\text { I }\end{array}$ & $\begin{array}{c}\text { Total } \\
\text { Response } \\
\text { s }\end{array}$ & $\begin{array}{c}\text { Mea } \\
\mathrm{n}\end{array}$ \\
\hline 1 & $\begin{array}{l}\text { Recommended } \\
\text { databases (MLA, } \\
\text { JSTOR, Project } \\
\text { Muse,RAS } \\
\text { bibliographies, KLG- } \\
\text { Online) }\end{array}$ & 0 & 2 & 7 & 4 & 13 & 3.15 \\
\hline 2 & $\begin{array}{l}\text { Search } \\
\text { strategies/Developin } \\
\text { g a topic \& keywords }\end{array}$ & 0 & 2 & 8 & 2 & 12 & 3.00 \\
\hline 3 & $\begin{array}{l}\text { Types of sources } \\
\text { (primary, secondary, } \\
\text { tertiary) and how to } \\
\text { evaluate }\end{array}$ & 1 & 4 & 6 & 2 & 13 & 2.69 \\
\hline 4 & $\begin{array}{l}\text { Reference sources } \\
\text { (print \& digital) }\end{array}$ & 1 & 2 & 8 & 2 & 13 & 2.85 \\
\hline 5 & $\begin{array}{l}\text { Digital collections } \\
\text { (BnF, Gallica, } \\
\text { European Library, } \\
\text { ARTFL,Projekt } \\
\text { Gutenberg, Yandex } \\
\text { dictionaries) }\end{array}$ & 0 & 3 & 5 & 4 & 12 & 3.08 \\
\hline 6 & $\begin{array}{l}\text { Library guide \& } \\
\text { handouts }\end{array}$ & 0 & 3 & 7 & 3 & 13 & 3.00 \\
\hline 7 & $\begin{array}{l}\text { Research impact } \\
\text { factors and citation } \\
\text { analysis (i.e., Arts \& } \\
\text { Humanities Citation } \\
\text { Index in Web of } \\
\text { Knowledge) }\end{array}$ & 2 & 5 & 4 & 3 & 14 & 2.57 \\
\hline 8 & $\begin{array}{l}\text { Setting up alerts in } \\
\text { databases \& journals }\end{array}$ & 1 & 5 & 5 & 2 & 13 & 2.62 \\
\hline 9 & $\begin{array}{l}\text { Library services } \\
\text { (e.g., interlibrary } \\
\text { loan, document } \\
\text { delivery) }\end{array}$ & 0 & 1 & 6 & 6 & 13 & 3.38 \\
\hline
\end{tabular}




\begin{tabular}{|c|c|c|c|c|c|c|c|c|c|}
\hline $\begin{array}{l}\text { Statis } \\
\text { tic }\end{array}$ & $\begin{array}{c}\text { Recom } \\
\text { mende } \\
d \\
\text { databas } \\
\text { es } \\
\text { (MLA, } \\
\text { JSTOR, } \\
\text { Project } \\
\text { Muse,R } \\
\text { AS } \\
\text { bibliogr } \\
\text { aphies, } \\
\text { KLG- } \\
\text { Online) }\end{array}$ & $\begin{array}{c}\text { Search } \\
\text { strategies/ } \\
\text { Developing } \\
\text { a topic \& } \\
\text { keywords }\end{array}$ & $\begin{array}{c}\text { Type } \\
\text { s of } \\
\text { sourc } \\
\text { es } \\
\text { (prim } \\
\text { ary, } \\
\text { seco } \\
\text { ndary } \\
\text {, } \\
\text { tertiar } \\
\text { y) } \\
\text { and } \\
\text { how } \\
\text { to } \\
\text { evalu } \\
\text { ate }\end{array}$ & $\begin{array}{c}\text { Refe } \\
\text { renc } \\
\text { e } \\
\text { sour } \\
\text { ces } \\
\text { (print } \\
\text { \& } \\
\text { digita } \\
\text { l) }\end{array}$ & $\begin{array}{c}\text { Digital } \\
\text { collecti } \\
\text { ons } \\
\text { (BnF, } \\
\text { Gallica, } \\
\text { Europe } \\
\text { an } \\
\text { Library, } \\
\text { ARTFL } \\
\text {,Projekt } \\
\text { Gutenb } \\
\text { erg, } \\
\text { Yandex } \\
\text { diction } \\
\text { aries) }\end{array}$ & $\begin{array}{c}\text { Libr } \\
\text { ary } \\
\text { guid } \\
\text { e \& } \\
\text { han } \\
\text { dout } \\
\text { s }\end{array}$ & $\begin{array}{c}\text { Rese } \\
\text { arch } \\
\text { impac } \\
t \\
\text { factor } \\
\text { s and } \\
\text { citatio } \\
n \\
\text { analy } \\
\text { sis } \\
\text { (i.e., } \\
\text { Arts \& } \\
\text { Huma } \\
\text { nities } \\
\text { Citati } \\
\text { on } \\
\text { Index } \\
\text { in } \\
\text { Web } \\
\text { of } \\
\text { Knowl } \\
\text { edge) }\end{array}$ & $\begin{array}{c}\text { Setti } \\
\text { ng } \\
\text { up } \\
\text { alert } \\
\text { s in } \\
\text { data } \\
\text { base } \\
\text { s \& } \\
\text { journ } \\
\text { als }\end{array}$ & $\begin{array}{c}\text { Libra } \\
\text { ry } \\
\text { servi } \\
\text { ces } \\
\text { (e.g., } \\
\text { interli } \\
\text { brary } \\
\text { loan, } \\
\text { docu } \\
\text { ment } \\
\text { deliv } \\
\text { ery) }\end{array}$ \\
\hline $\begin{array}{l}\text { Min } \\
\text { Value }\end{array}$ & 2 & 2 & 1 & 1 & 2 & 2 & 1 & 1 & 2 \\
\hline $\begin{array}{l}\text { Max } \\
\text { Value }\end{array}$ & 4 & 4 & 4 & 4 & 4 & 4 & 4 & 4 & 4 \\
\hline Mean & 3.15 & 3.00 & 2.69 & 2.85 & 3.08 & 3.00 & 2.57 & 2.62 & 3.38 \\
\hline $\begin{array}{l}\text { Varia } \\
\text { nce }\end{array}$ & 0.47 & 0.36 & 0.73 & 0.64 & 0.63 & 0.50 & 1.03 & 0.76 & 0.42 \\
\hline $\begin{array}{l}\text { Stand } \\
\text { ard } \\
\text { Devia } \\
\text { tion }\end{array}$ & 0.69 & 0.60 & 0.85 & 0.80 & 0.79 & 0.71 & 1.02 & 0.87 & 0.65 \\
\hline $\begin{array}{l}\text { Total } \\
\text { Resp } \\
\text { onse } \\
\text { s }\end{array}$ & 13 & 12 & 13 & 13 & 12 & 13 & 14 & 13 & 13 \\
\hline
\end{tabular}

\section{Has this experience increased your confidence in conducting library research?}

\begin{tabular}{|c|l|l|c|c|}
\hline$\#$ & Answer & Response & $\%$ \\
\hline 1 & Yes & 12 & $86 \%$ \\
2 & No & 2 & $14 \%$ \\
\hline & Total & 14 & $100 \%$ \\
\hline
\end{tabular}


Max Value

Mean

Variance

\section{In the future, will you seek out a librarian for assistance with your research assignments?}

\begin{tabular}{|c|l|c|c|c|}
\hline$\#$ & Answer & Response & $\%$ \\
\hline 1 & Yes & 12 & $86 \%$ \\
\hline 2 & No & 2 & $14 \%$ \\
\hline & Total & 14 & $100 \%$ \\
\hline
\end{tabular}

\section{Statistic}

\section{What section of Introduction to Graduate Studies did}

\section{you take?}

\begin{tabular}{|c|l|l|c|c|}
\hline$\#$ & Answer & Response & $\%$ \\
\hline 1 & French 720 & 3 & $25 \%$ \\
\hline 2 & German & 700 & 3 & $25 \%$ \\
3 & Slavic 740 & 6 & $50 \%$ \\
\hline & Total & 12 & $100 \%$ \\
\hline
\end{tabular}

\section{Statistic}

Value

Min Value

Max Value

Mean

2.25

Variance

0.75

Standard Deviation

0.87

Total Responses 


\begin{abstract}
Notes
${ }^{1}$ This is a topic that makes regular appearances in academic trade publications

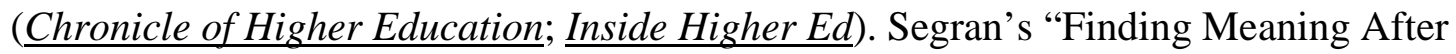
Academe” highlights the difficulties faced by humanities PhDs who leave the academy. Straumsheim’s “'Alt-Ac’ Realities” describes a study that shows how students are woefully unprepared to face the so-called “alt-ac” job market. In the mainstream press, Tuhus-Dubrow’s “The Repurposed PhD” discusses < versatilephd.com>, an “online community dedicated to non-academic and non-faculty careers for PhDs in humanities, social science and STEM," and a "Beyond Academia” conference held at UC-Berkeley since 2013.

${ }^{2}$ We are well aware that there are graduate programs that have a much more developed curriculum in digital humanities. However, for French programs that do not currently have a digital humanities component integrated into their curriculum, our experiment could serve as a beginning model. It allowed students to connect with people and resources on and off campus, thereby developing more expertise.

${ }^{3}$ We credit our colleague in Germanic Languages \& Literatures, Dr. Leonie Marx, who had the idea for the conference.
\end{abstract}




\section{Works Cited}

Bean, Teresa M., and Sabrina N. Thomas. “Being Like Both: Library Instruction Methods That Outshine the One-Shot.” Public Services Quarterly 6.2-3 (2010): 237-49.

Dewey, Barbara I. “The Embedded Librarian.” Resource Sharing \& Information Networks 17.1-2 (2004): 5-17.

Durand, Alain-Philippe. “A Certain Tendency of French/Francophone Studies in the United States.” French Review 86.6 (May 2013): 1101-12.

Patel, Vimal. “Proposal to Offer Job-Friendly English PhD Draws Criticism.” Chronicle of Higher Education 15 Sept. 2014. <chronicle.com/article/Proposal-to-Offer-JobFriendly/148779>.

Schulte, Stephanie J. "Embedded Academic Librarianship: A Review of the Literature.” Evidence Based Library and Information Practice 7.4 (2012): 122-38.

Segran, Elizabeth. “Finding Meaning After Academe.” Chronicle of Higher Education 7 July 2014. <chronicle.com/article/Finding-Meaning-After-Academe/147489>.

Straumsheim, Carl. ““Alt-Ac’ Realities.” Inside Higher Ed 30 April 2013. <www.insidehighered.com/news/2013/04/30/survey-shows-humanities-gradstudents-rarely-expect-pursue-alt-ac-careers>.

Tuhus-Dubrow, Rebecca. “The Repurposed PhD: Finding Life After Academia—and Not Feeling Bad About It.” New York Times 1 Nov. 2013. <www.nytimes.com/2013/11/03/education/edlife/finding-life-after-academia-andnot-feeling-bad-about-it.html?pagewanted=all\&_r=0NYTimes.com>. 